\title{
Rising trend in cesarean sections: a retrospective study at tertiary care hospital in Jammu
}

\author{
Shazia Zargar, Nikita Gandotra* \\ Department of Obstetrics and Gynecology, SMGS Hospital, Jammu, Jammu and Kashmir, India
}

Received: 26 February 2021

Revised: 08 April 2021

Accepted: 09 April 2021

\section{*Correspondence:}

Dr. Nikita Gandotra,

E-mail: nikigandotra@gmail.com

Copyright: ( $)$ the author(s), publisher and licensee Medip Academy. This is an open-access article distributed under the terms of the Creative Commons Attribution Non-Commercial License, which permits unrestricted non-commercial use, distribution, and reproduction in any medium, provided the original work is properly cited.

\begin{abstract}
Background: The uncontrolled wave of cesarean rates has increased globally which has resulted in a significant amount of maternal mortality and morbidity. The present study aims to evaluate the trend in cesarean section rates in Jammu, India.

Methods: The present retrospective study was carried out at the department of Obstetrics and Gynecology, SMGS Hospital, Jammu, India. We collected data based on total number of deliveries and cesarean sections performed at the hospital during (March2015-Feb2020) along with indications for CS.

Results: The percentage of cesarean sections has increased drastically from $39.4 \%$ during (2015-16) to $49.9 \%$ in (2019-20). The study shows that the most common indication for CS is post CS followed by NPOL, Fetal distress, breech, APH, CPD, PIH and others.

Conclusions: There is a growing concern among public and health care providers regarding the escalating and uncontrolled trend of cesarean sections which needs to be curtailed within optimal limits recommended by WHO.
\end{abstract}

Keywords: Cesarean, Deliveries, Indications

\section{INTRODUCTION}

From the last few decades there has been a growing trend in cesarean section rates both in developed and under developed countries. With the steadily increase in both primary and repeated cesarean birth rates, the public in particular health care providers are facing a challenging situation. ${ }^{1-3}$ In England, France, Sweden and twelve Latin American countries the cesarean section rates are above $15 \%$ with highest $40 \%{ }^{4-7}$

Countries like Brazil, Iran and Mexico reported CS rates $85.6 \%, 85.8 \%$ and $92 \%$ respectively. ${ }^{8,9}$ The World Health Organization suggested that CS rates should not be ideally higher than $10 \%$ to $15 \%{ }^{10}$

In India, ICMR conducted a study in 1980 and reported that in teaching hospitals the CS rate is touching to $14 \%$. On comparing the data from 30 teaching hospitals/medical colleges between (1993-94) and (199899) there has been an escalating trend with an increase from $21.8 \%$ to $25.4 \% .^{11}$

What was worth to note that $42.4 \%$ were primigravidas and $31 \%$ were from rural areas? One of the studies over two period of years in an urban area of India reported that CS rates corresponding to public and charitable sectors were 20 and $38 \%$ respectively, for private sectors the rate was around $47 \% .^{12}$

The data collected by National Family Health Survey during (1992-93), (1998-99), (2005-06) and (2015-16) shows that CS rates are exhibiting increasing trend.

The CS rate of India during (1992-93) was 2.9\% which is now $17.2 \%$ at present which clearly unfolds its escalating trend and it is evident that it has increased manifold in the last two decades. 
Table 1: Percentage of women who had undergone caesarean section from NFHS-1(1992-93), NFHS-2 (1998-99), NFHS-3 (2005-06) and NFHS-4 (2015-16).13-16.

\begin{tabular}{|lllll|}
\hline State/ Country & $\begin{array}{l}\text { NFHS-1 } \\
(\mathbf{1 9 9 2 - 9 3 )}\end{array}$ & $\begin{array}{l}\text { NFHS-2 } \\
(\mathbf{1 9 8 - 9 9 )}\end{array}$ & $\begin{array}{l}\text { NFHS-3 } \\
(\mathbf{2 0 0 5 - 0 6 )}\end{array}$ & $\begin{array}{l}\text { NFHS-4 } \\
(\mathbf{2 0 1 5 - 1 6 )}\end{array}$ \\
\hline India & 2.9 & 7.1 & 10.6 & 17.2 \\
\hline Jammu and Kashmir & 5.7 & 10.6 & 14.1 & 33.1 \\
\hline Delhi & 4.6 & 13.4 & 12.0 & 23.7 \\
\hline Himachal Pradesh & 1.6 & 6.8 & 13.1 & 16.7 \\
\hline Haryana & 2.3 & 4.2 & 5.0 & 11.7 \\
\hline Punjab & 4.2 & 8.3 & 14.4 & 24.6 \\
\hline Utter Pradesh & 0.6 & 2.7 & 5.9 & 9.4 \\
\hline Maharashtra & 3.4 & 9.9 & 15.6 & 20.1 \\
\hline Karnataka & 3.7 & 11.0 & 15.3 & 23.6 \\
\hline Bihar & 1.1 & 3.0 & 4.1 & 8.2 \\
\hline Rajasthan & 0.7 & 3.0 & 4.2 & 31.4 \\
\hline Goa & 13.7 & 20.0 & 25.7 & \\
\hline
\end{tabular}

From the Table 1, we observe that every state shows an increment in CS rates from (1992-2016) wherein Jammu and Kashmir displays a highest spike in it. Because of lack proper standard classification system for indications of CS, different institutions report different indications for CS. ${ }^{17-19}$

Still in general, indications have been classified interns of medical and non-medical reasons. Fetal distress, especially by its constant monitoring through electronic systems, breech presentation, abdominal delivery of growth-retarded infant, increased maternal body mass, placenta previa, prematurity, multiple gestation, previous $\mathrm{CS}$, failure to progress for labor pain are some medical indications of $\mathrm{CS} .^{20-21}$

On the other hand, non-medical indications include maternal request for elective CS delivery, the percentage of which ranges from $0.3 \%$ to $14 \%$ worldwide. ${ }^{22}$ Cultural ethos, for instance, in China the baby's delivery date is chosen as per the future luck of baby, fear of pain and genital modifications after vaginal delivery, easy for health care professionals and mother, profit interests among health care providers may alter the decision making which in turn leads to more cesarean deliveries. ${ }^{23-}$ 25

Other non-medical factors that motivate patients for cesarean deliveries include the fear among patients of not finding their own consultant on right time, fear from suffering long labor, defensive approach of obstetricians to avoid any negligence claims. Aim of our study was to study the rising trend of cesarean sections in our hospital.

\section{METHODS}

This is a retrospective study carried out at the department of Obstetrics and Gynaecology, SMGS Hospital, Jammu, India. We collected a data based on total number of deliveries and cesarean sections performed at the hospital during (March2015-Feb2020).

\section{Inclusion criteria}

All the patients who underwent for CS during the study period were included in the study. Vaginal deliveries, instrumental deliveries, indications for CS were also collected from record section of the hospital. Other information vital for the indication of CS was included in the study while as less or rare information were omitted.

\section{Exclusion criteria}

Patients refusing to take part in the study. All statistical calculations were done using SPSS (statistical package for the social science) SPSS 17 version statistical program for Microsoft Windows. Results were tabulated.

\section{RESULTS}

In this section we shall present some important results pertaining to total no. of deliveries and cesarean sections year wise and indications for CS in a compact tabular form. Maximum patients in our study belonged to age group 21-30 years (Table 2).

Table 2: Demographic profile (age).

\begin{tabular}{|l|l|}
\hline Age group & Percentage \\
\hline$<\mathbf{2 0}$ & 3.2 \\
\hline $\mathbf{2 1 - 3 0}$ & 68 \\
\hline $\mathbf{3 1 - 4 0}$ & 26.1 \\
\hline$>\mathbf{4 0}$ & 2.7 \\
\hline Total & 100 \\
\hline
\end{tabular}

From the Table 3, we observe year wise distribution of total deliveries and cesarean sections performed at the hospital. It is evident that annual no. of deliveries 
increased from 18659 to 27921, the percentage of cesarean sections has increased drastically from $39.4 \%$ during (2015-16) to $49.9 \%$ in (2019-20), the biggest spike in annual percentage of CS was observed in (2018-19).

Table 3: Total deliveries and caesarean section rate from 2015-2020.

\begin{tabular}{|llll|}
\hline Year & Total deliveries & Cesarean section & Percentage \\
\hline $\mathbf{2 0 1 5}-16$ & 18659 & 7356 & 39.4 \\
\hline $\mathbf{2 0 1 6 - 1 7}$ & 20097 & 8095 & 40.3 \\
\hline $\mathbf{2 0 1 7}-18$ & 22725 & 9569 & 42.1 \\
\hline $\mathbf{2 0 1 8}-19$ & 25812 & 11921 & 46.2 \\
\hline $\mathbf{2 0 1 9 - 2 0}$ & 27921 & 13920 & 49.9 \\
\hline
\end{tabular}

Table 4: Commonest indications of caesarean section, their frequency and percentage distribution.

\begin{tabular}{|c|c|c|c|c|c|}
\hline \multirow{2}{*}{ Indication } & \multicolumn{5}{|l|}{ Year } \\
\hline & 2015-16 & 2016-17 & 2017-18 & 2018-19 & 2019-20 \\
\hline Post CS & $2036(27.7 \%)$ & $2884(35.6 \%)$ & $3481(36.4 \%)$ & $4455(37.4 \%)$ & $4863(34.9 \%)$ \\
\hline NPOL & $1327(18.0 \%)$ & $1641(20.3 \%)$ & $2098(21.9 \%)$ & $2294(19.2 \%)$ & $2584(18.6 \%)$ \\
\hline Fetal Distress & $983(13.4 \%)$ & $1052(13.0 \%)$ & $1051(11.0 \%)$ & $1102(9.2 \%)$ & $1786(12.8 \%)$ \\
\hline Breech & $931(12.7 \%)$ & $831(10.3 \%)$ & $927(9.7 \%)$ & $1653(13.9 \%)$ & $1302(9.4 \%)$ \\
\hline APH & $811(11.0 \%)$ & $583(7.2 \%)$ & $697(7.3 \%)$ & $1195(10.0 \%)$ & $1507(10.8 \%)$ \\
\hline CPD & $368(5.0 \%)$ & $419(5.2 \%)$ & $614(6.4 \%)$ & $379(3.2 \%)$ & $690(5.0 \%)$ \\
\hline PIH & $353(4.8 \%)$ & $273(3.4 \%)$ & $463(4.8 \%)$ & $631(5.3 \%)$ & $1015(7.3 \%)$ \\
\hline Others & $547(7.4 \%)$ & $412(5.1 \%)$ & $238(2.5 \%)$ & $212(1.8 \%)$ & $173(1.2 \%)$ \\
\hline Total & 7356 & 8095 & 9569 & 11921 & 13920 \\
\hline
\end{tabular}

Table 4, discusses various types of indications of CS, we observe that the most common indication for CS is Post CS followed by NPOL, Fetal distress, Breech, APH, CPD, PIH and others.

The percentage of post CS indication of cesarean section increases from $27.7 \%$ during $(2015-16)$ to $37.4 \%$ in (2018-19) and then drops to $34.4 \%$ in (2019-20). The percentage of other indications of CS remains fluctuating with no significant percent increment or decrement during the study period

\section{DISCUSSION}

In the present study, the CS rate has dramatically increased from $39.4 \%$ to almost $50 \%$ (10.5\% hike) which clearly shows an escalating trend. From Table 1, we observe that as per the NFHS-3, the CS rate in India was $10.6 \%$ which lies within allowable limits of (10-15) percent recommended by WHO.

However, onwards from 2015, there has been a rising trend in CS much beyond recommended level, NFHS-4 reports $17.2 \%$ of CS in India during (2015-16). As per NFHS-2, J\&K had a stable CS percentage of 10.6 during (1998-99), thereafter it has witnessed an elevated growth of CS rates and reached to $33.1 \%$ during (2015-16), NFHS-4. In Jammu CS rate has reached to $49.9 \%$ from $39.4 \%$, an increment of $10.5 \%$ in five years which is almost same increment of $8.01 \%$ reported by Qazi et al. ${ }^{26}$
In our study we have observed that most common indication of CS as post CS constituting between (27.734.9) percent of indications followed by NPOL accounting for (18-21.9) percent of indications.

Rest of the indications of CS in terms of decreasing percentage order were fetal distress, breech, APH, CPD and PIH. Other studies due to Barber et al, Stasieluk et al, Kolas et al and Qazi et al have also reported post CS followed by NPOL, as most common indication of CS. ${ }^{26-}$ 29

However, studies conducted by WHO in nine Asian countries reported that most common indication of $\mathrm{CS}$ are previous CS accounting (24.2\%), CPD (22.66\%), fetal distress $(20.5 \%)$, breech along with other abnormalities $(12.5 \%)^{1}$

It was also reported in the survey that operative vaginal delivery and all types of CS were significantly linked with elevated risk of maternal mortality and morbidity in comparison to normal vaginal deliveries. One of the significant reason for rise in CS in post CS group was the denial of consent for labor much similar to what other studies due to Brber et al and Stasieluk et al reported. ${ }^{27,28}$

However, Mackenzie et al have reported that it is maternal request which is most common indication for CS constituting around (23\%) while as Nazneen et al reported only $(8 \%)$ indications for CS constitute maternal request. $^{30,31}$ But we do not find maternal request 
indication for CS to be of much importance in the present study.

\section{CONCLUSION}

There is a growing concern among public and health care providers regarding the escalating and uncontrolled trend of cesarean sections, the reasons for this are multifaceted that include both medical indications and non-medical reasons that have been already highlighted in this study. The present rate of CS in Jammu is almost (50\%) which is way beyond the allowable limit of (10-15) \% proposed by WHO for its optimal use.

However, the logical and responsible diminution of CS is not a short and straight forward task; it will consume lots of time and efforts. In order to minimize and limit this uncontrolled wave of CS ethically within recommended levels, multiple efforts are needed that include establishment of counseling cells for mothers at gross root level that encourage them for vaginal deliveries, development of policies to ensure optimal use of CS which is possible by closely monitoring CS rates along with feto-maternal outcomes, evaluating medical indications leading to $\mathrm{CS}$ in an unbiased and careful manner, improving labor analgesia, remaining ethically bound for optimal patient benefits rather than selfprofitability.

\section{ACKNOWLEDGMENTS}

We are thankful to our patients who participated in the study.

Funding: No funding sources

Conflict of interest: None declared

Ethical approval: The study was approved by the Institutional Ethics Committee

\section{REFERENCES}

1. Lomas J. Holding back the tide of caesarean section. BMJ 1988;297(6648):569-70.

2. Bottoms SF, Rosen MG, Sokol RG. The increase in the caesarean birth rate. $\mathrm{N}$ Engl $\mathrm{J}$ Med. 1980;302(10):559-63.

3. Shearer EC. Education of vaginal birth after caesarean section. Birth. 1982;9(1):31-4.

4. Mayor S. Caesarean section rate in England reaches 22\%. BMJ. 2002;324:1118.

5. Guihard P, Blondel B, Trends in risk factor for caesarean sections in France between 1981 and 1995; lessons for reducing the rates in future. $\mathrm{Br} \mathrm{J}$ Obstet and Gynaec. 2001;108(1):48-55.

6. Odlind V, Haglund B, Pakkanen M, Otturblad Olausson P. Deliveries, mothers and newborn infants in Sweden, 1973-2000.Trends in obstretics as reported to the Swedish Medical Birth Registar. Acta Obstet Gynaecol Scand. 2003;82(6):516-28.
7. Belizan JM, Althabe F, Barros FC, Showalter E, Castro A, Bastian H, et al. Rates and implications of caesarean sections in Latin America: ecological study. BMJ. 1999;319(7222):1397-1402.

8. Ghotbi F, Akbari Sene A, Azargashb E, Shiva F, Mohtadi M, Zadehmodares S, et al. Women's knowledge and attitude towards mode of delivery and frequency of cesarean section on mother's request in six public and private hospitals in Tehran, Iran, 2012. J Obstet Gynaecol Research. 2014;40(5):1257-66.

9. Mendoza-Sassi RA, Cesar JA, Silva PR, Denardin G, Rodrigues MM. Risk factors for cesarean section by category of health service. J Public Health. 2010;44(1):80-90.

10. Robson, Michel S. Can the high Caesarean section rates be reduced? Recent advance in Obstet and Gynaec. 2004;22:71-84.

11. Kambo I, Bedi N, Dhillon BS, Saxena NC. A critical appraisal of cesarean section rates at teaching hospitals in India. Int $\mathrm{J}$ Gynecol Obstet. 2002;79(2):151-8.

12. Sreevidya S, Sathiyasekaran BW. High caesarean rates in Madras (India): a population-based cross sectional study. BJOG: An Int J Obstet Gynaecol. 2003;110(2):106-11.

13. International Institute for Population Sciences, Mumbai National Family Health Survey (NFHS-1) 1992-93.

14. International Institute for Population Sciences, Mumbai National Family Health Survey (NFHS-2) 1998-99.

15. International Institute for Population Sciences, Mumbai National Family Health Survey (NFHS-3) 2005-06.

16. International Institute for Population Sciences, Mumbai (2017) National Family Health Survey (NFHS-4) 2015-16 India Fact sheet.

17. Stanton C, Ronsmans C. Recommendations for routine reporting on indications for caesarean delivery in developing countries. Birth. 2008;35(3):204-11.

18. Torloni MR, Betran AP, Souza JP, Widmer M, Allen $\mathrm{T}$, Gulmezoglu M, et al. Classifications for caesarean section: a systematic review. PLoS One. 2011;6(1):e1456.

19. Singh G, Gupta ED. Rising incidence of caesarean section in rural area in Haryana, India: a retrospective analysis. Internet $\mathbf{J}$ Gynecol Obstetr. 2013;17(2):1-5.

20. Cuningham FG, Leveno KJ, Bloome SL, Hauth JC, Gilstrap LC, Wenstrom KD. Preterm birth. In: Rouse D, Spong C, Rainey B, Wendel GD, eds. Williams Obstetrics. $22^{\text {nd }}$ ed. New York: McGraw-Hill. 2005:865-6.

21. Lavender T, Hofmeyr GJ, Neilson JP, Kingdon C, Gyte GML. Caesarean section for non-medical reasons at term. Cochrane Database Syst Rev. 2006;3:CD004660. 
22. McCourt C, Weaver J, Statham H, Beake S, Gamble J, Creedy DK. Elective cesarean section and decision making: a critical review of literature. Birth. 2007;34(1):65-79.

23. Mi J, Liu F. Rate of caesarean section is alarming in China. Lancet. 2014;383(9927):1463-4.

24. Dosa L. Caesarean section delivery and increasingly popular option. Bull World Health Organ. 2001;79:1173.

25. De Muylder X. Caesarean section in developing countries: Some considerations. Health Policy Plan. 1993;8:101-12

26. Qazi M, Saqib N Rising trend of caesarean section in a tertiary hospital over half decade: a retrospective study. Int J Repr, Contraception, Obstet and Gynec. 2018;7(10):4097-102

27. Barber EL, Lundsberg LS, Belanger K, Pettker CM, Funai EF, Illuzzi JL. Indications contributing to the increasing cesarean delivery rate. Obstet Gynecol. 2011;118(1):29-38.
28. Stasiełuk A, Langowicz I, Kosińska-Kaczyńska K, Pietrzak B, Wielgoś M. Is the epidemic of cesarean sections the result of more liberal indications? Gynecol Poland. 2012;83(8):604-8.

29. Kolås T, Hofoss D, Daltveit AK, Nilsen ST, Henriksen T, Häger R, et al. Indications for cesarean deliveries in Norway. Am J Obstet Gynecol. 2003;188(4):864-70.

30. Mackenzie IZ, Cooke I, Annan B. Indications for cesarean section in a consultant unit over the decades. J Obstet Gynecol. 2003;23(3):233-8.

31. Nazneen R, Begum RA, Sultana K. Rising Trend of Caesarean Section in a Tertiary Hospital Over a Decade. Journal of Bangladesh College of Physi and Surg. 2011;29(3):126-32.

Cite this article as: Zargar S, Gandotra N. Rising trend in cesarean sections: A retrospective study at tertiary care hospital in Jammu. Int J Reprod Contracept Obstet Gynecol 2021;10:1958-62. 